\title{
SUPPORT SYSTEM KELUARGA DALAM PENCEGAHAN KETOASIDOSIS DIABETIK PADA ANAK DENGAN DM TIPE 1
}

\author{
Ana Fitria Nusantara ${ }^{1)}$,Sunanto ${ }^{2)}$, Achmad Kusyairi ${ }^{3)}$ \\ Program Studi Sarjana Keperawatan, STIKes Hafshawaty Pesantren Zainul Hasan \\ email: anafitriaachmad@gmail.com
}

\begin{abstract}
Abstrak
Ketoasidosis diabetik (KAD) merupakan komplikasi akut diabetes melitus tipe 1 yang ditandai dengan dehidrasi, kehilangan elektrolit, asidosis dan disebabkan oleh pembentukan keton yang berlebihan. Keadaan ini merupakan gangguan metabolisme yang paling serius dan mengancam jiwa. Namun demikian kejadian KAD dapat dicegah dengan beberapa cara, salah satunya adalah dengan menejemen diabetik yang benar. Penelitian bertujuan mengidentifikasidukungan keluarga dalam mencegah ketoasidosis diabetik.Desain penelitian kualitatif digunakan pada penelitian ini dengan pendekatan phenomenology. Data dikumpulkan dengan tehnik wawancara tidak terstruktur kemudian dianalisis dengan tehnik Van Manen.Hasil penelitian menunjukkan bahwa support sistem keluarga dapat dilakukan dengan cara membawakan bekal makan atau minum untuk kegiatan di luar rumah, mengkomunikasikan penyakit anak kepada pihak lain di luar rumah (sekolah, tetangga, saudara), melakukan injeksi insulin, pengawasan diet, serta kunjungan rutin ke rumah sakit. Anak dengan DM tipe 1 berada pada usia yang sangat muda sehingga dalam hal perawatan dan penatalaksanaan diabetesnya sangat tergantung pada orang tua selaku penanggung jawab dalam perawatan anak. Dukungan orang tua dalam perawatan anak dengan DM tipe 1 sangat berdampak pada pencegahan terjadinya komplikasi seperti ketoasidosis diabetik.
\end{abstract}

Kata kunci: support system, ketoasidosis diabetik, diabetes mellitus tipe 1

\begin{abstract}
Diabetic ketoacidosis (DKA) is an acute complication of type 1 diabetes mellitus which is characterized by dehydration, loss of electrolytes, acidosis and is caused by excessive ketone formation. This situation is the most serious and life-threatening metabolic disorder. However, the incidence of DKA can be prevented in several ways, one of them is correctly diabetic management. The study aims to identify family support in preventing diabetic ketoacidosis. A qualitative research design was used in this study with a phenomenology approach. Data was collected using unstructured interview techniques and then analyzed with Van Manen techniques. The results showed that family support system are by bringing food or drink supplies to the activities outside the home, communicating children's illnesses to other parties outside the home (school, neighbors, relatives), injecting insulin, supervising diet, and regular visits to hospital. Children with type 1 diabetes are at a very young age so that in case of diabetes care and management aredepent on parents as the responsible person in child care. Parental support to the children with type 1 DM are greatly affects to the prevention of complications such as diabetic ketoacidosis.
\end{abstract}

Keywords: support system, ketoacidosis diabetic, diabetes mellitus type 1

\section{PENDAHULUAN}

Diabetes mellitus salah satu penyakit kronis yang terus mengalami peningkatan setiap tahun dari prevalensinya semakin meningkat dari tahun ke tahun. Wordl Health Organization (WHO) memperkirakan jumlah penderita diabetes mellitus mengalami kenaikan. Di Indonesia yang pada tahun 2000 berjumlah 8,4 juta meningkat menjadi kurang lebih 21,3 juta pada 2030. Indonesia menduduki posisi keempat di dunia dengan jumlah penderita diabetes mellitus terbanyak setelah India, China, dan Amerika.

Sampai saat ini Indonesia adalah merupakan Negara berkembang yang diikuti oleh gaya hidup masyarakat yang tidak sehat. Tinginya pendapatan menyebabkan kecenderungan untuk melakukan gaya hidup yang tidak baik bagi kesehatan. Hal ini tentunya juga berdampak pada kesehatan dari keturunannya. Diabetes mellitus tipe 1 merupakan penyakit yang disebabkan oleh factor genetik.

Penatalaksanaan diabetes mellitus akan memakan waktu yang lama. Oleh karena diabetes 
mellitus tipe 1 adalah penyakit yang akan diderita seumur hidup dan sangat rentan terja dikomplikasi sehingga membutuhkan perawatan yang lengkap dan berkelanjutan, tidak hanya pengobatan tetapi penderita juga dituntut untuk melakukan perubahan gaya hidup. Banyak penderita yang akhirnya tidak konsisten menjalankan terapi dan menjadi putus asa dengan program terapi yang harus dijalani sementara penyakit tidak dapat sembuh. Pada awal terdiagnosa penderita diabetes cenderung mematuhi program terapi, akan tetapi dengan berjalannya waktu dan keluhan sudah menghilang maka pada tahap inilah penderita merasa sudah sembuh dan tidak menjalankan terapinya.

Ketoasidosis diabetikuma dalah komplikasi akut dari diabetes mellitus tipe 1 yang paling sering terjadi pada anak dengan angka morbiditas dan mortalitas yang tinggi. Beberapa faktor yang menjadi penyebabnya adalah kesalahan pengelolaan dosis insulin atau stress, system regulasi pengiriman insulin, dan ketidakpatuhan akan terapi insulin (Chafe dkk, 2015). Faktor yang mempengaruhi kepatuhan salah satunya adalah dukungan dari keluarga, dengan adanya dukungan dari keluarga diharapkan penderita akan merasa senang dan tentram, karena dengan dukungan tersebut akan menimbulkan kepercayaan dirinya untuk menghadapi atau mengelola penyakitnya lebih baik (Susanti dan Sulistyarini, 2013).

Penelitian ini bertujuan untuk mengidentifikasi bentuk dukungan keluarga dalam pencegahan kejadian ketoasidosis diabetik.

\section{METODE PENELITIAN}

Penelitian ini menggunakan metode penelitian kualitatif dengan pendekatan Phenomenology Hermenuetic. Dimana data dikumpulkan menggunakan metode wawancara tidak terstruktur pada 24 responden yang terdiri dari 12 orangtua dan 12 orang anak penderita DM Type I. Wawancara berlangsung selama 45-60 menit. Hasil wawancara ditranskrip dan untuk mendapatkan tema, hasil wawancara dianalisis menggunakan Van Mannen.

\section{HASIL DAN PEMBAHASAN}

\section{Hasil Penelitian}

Hasil penelitianini akan memaparkan tentang bentuk support systemkeluarga yang dalam hal ini adalah orang tua baik ayah ataupun ibu dalam pencegahan terjadinya ketoasidosis diabetik pada anak dengan diabetes melitus tipe 1. Data akan disajikan dalam bentuk tabel dan narasi.

\section{Karakteristik Partisipan}

Tabel Distribusi Partisipan, meliputi Usia Partisipan, Jenis Kelamin dan Tingkat semester.

\begin{tabular}{lcc}
\hline \multicolumn{1}{c}{ Variabel } & $\mathrm{n}$ & $\%$ \\
\hline Lama terdiagnosa DM tipe 1 & & \\
- 1 Tahun & 4 & $33 \%$ \\
- 2 Tahun & 5 & $42 \%$ \\
- 6 Tahun & 3 & $25 \%$ \\
Serangan KAD ke- & & \\
- 1 & 2 & $17 \%$ \\
-2 & 4 & $33 \%$ \\
-3 & 5 & $42 \%$ \\
-5 & 1 & $8 \%$ \\
\hline
\end{tabular}

a. Dukungan Orang Tua Dalam Pencegahan KAD Pada Anak Dengan Dm Tipe 1

Tema1 : Membawakan Bekal Makan atau Minum Untuk Kegiatan Di Luar Rumah

Berdasarkan hasil wawancara dengan partisipan didapatkan bahwa untuk menghindari konsumsi makan diluar ketentuan diet orang tua membekali pasien makanan dan minuman dari rumah ketika pasien ada kegiatan di luar rumah seperti sekolah, ekstrakurikuler dan ketika acara keluarga.

Tema2 : Mengkomunikasikan tentang Penyakit Kepada Orang Lain di Luar Rumah (Sekolah/ Teman-teman, Tetangga)

Berdasarkan hasil wawancara dengan partisipan didapatkan bahwa untuk mencegah halhal yang tidak diinginkan terjadi ketika pasien berada di luar rumah orang tua mengkomunikasikan kepada guru di sekolah, teman-teman pasien, tetangga serta saudara bahwa putra atau putrinya menderita menyakit DM tipe 1 seingga tidak bisa mengkonsumsi atau melakukakan sesuatu yang tubuh pasien tidak toleransi, harus membawa obat injeksi dan melakukan injeksi pada jam yang sudah ditentukan.

\section{Tema 3: Melakukan injeksi insulin}

Berdasarkan hasil wawancara dengan partisipan didapatkan bahwa injeksi insulin dilakukan sebelum makan dengan dosis yang sudah ditentukan oleh dokter. Ketika anak sekolah dan harus melakukan injeksi pada saat anak masih di sekolah maka orang tua membawakan insulin ke sekolah. 


\section{Tema 4: Pengawasan diet}

Berdasarkan hasil wawancara dengan partisipan didapatkan bahwa partisipan mengikuti pengaturan pola makan yang ditentukan. Orang tua menyiapkan makanan di rumah dengan porsi sesuai yang diajarkan oleh petugas kesehatan. Pengaturan porsi tidak ditimbang karena tidak memiliki timbangan di rumah tetapi dilakukan berdasarkan perkiraan dan takaran seperti nasi 4 sendok dan sayur satu mangkok kecil setiap kali makan. Untuk jenis makanan disesuaikan dengan bahan yang ada di rumah dan sesuai kemampuan orang tua untuk membeli. Orang tua membatasi konsumsi nasi putih dan minuman manis untuk anak. Untuk waktu makan dilakukan sebanyak tiga kali dalam satu hari dan tidak lebih dari jam lima sore. Diantara tiga kali jadwal makan tersebut kadangkala diselingi dengan cemilan berupa buah dan makanan ringan yang dibuat sendiri oleh orang tua. Semua partisipan orang tua mengupayakan makanan dan camilan anak ketika di rumah adalah hasil masakan orang tua dengan bahan yang cocok untuk anak menurut orang tua.

\section{Tema 5: Kunjungan rutin ke rumah sakit}

Berdasarkan hasil wawancara dengan partisipan didapatkan bahwa kunjunganl rutin dilakukan setiap bulan ke rumah sakit sesuai jadwal. Apabila akan ada libur hari tertentu atau libur lama maka kunjungan dilakukan sebelum libur agar tidak kehabisan insulin. Ketika melakukan kunjungan ke rumah sakit partisipan juga melakukan konseling dengan dokter tentang beberapa hal yang terjadi atau dialami oleh anak selama bulan sebelumnya. selain untuk ambil insulin dan konseling, pada waktu kunjungan tersebut partisipan juga diperiksa kadar glukosa darah. Untuk pemeriksaan GD ini partisipan hanya melakukan ketika kunjungan bulanan ke rumah sakit tersebut.

\section{Pembahasan}

\section{a. Dukungan Orang Tua Dalam Pencegahan Kad pada Anak Dengan DM Tipe 1}

\section{Tema1 : Membawakan Bekal Makan atau Minum Untuk Kegiatan di Luar Rumah}

Banyak upaya yang dilakukan orang tua untuk memenuhi aturan menejemen diet dibetes pada anak, salah satu yang dilakukan adalah dengan membawakan bekal makan dan minum dari rumah untuk kegiatan anak di luar rumah baik di sekolah ataupun tempat lain. Pengaturan diet merupakan poin penting dalam mencegah kejadian komplikasi diabetes. Pada usia <15 tahun menejemen diabetes sangat tergantung dengan orang tua selaku pendamping utama anak. Sehingga kesadaran orang tua akan pentingnya kepatuhan terhadap menejemen diet sangat penting.

Diagnosis diabetes mellitus tipe 1 sering menyebabkan KAD pada usia anak. Kejadian KAD pada anak seringkali disebabkan oleh faktor diet yang tidak sesuai. Pengetahuan orang tua tentang diet sangat dipengaruhi oleh pendidikan. Tingkat pendidikan orang tua sangat berpengaruh terhadap keberhasilan pendidikan kesehatan bagi orang tua penderita diabetes mellitus tipe 1 dalam pencegahan KAD. Orang tua dengan tingkat pendidikan yang lebih tinggi itu cenderung protektif terhadap terjadinya KAD. Di indonesia anak yang terdiagnosa diabetes mellitus tipe 1 dengan orang tua yang pernah menempuh pendidikan kurang dari 9 tahun memiliki resiko yang signifikan mengalami ketoasidosis diabetik dibandingkan dengan orang tua yang memiliki pendidikan lebih dari 12 tahun (Usher-Smith et al. 2011).

Ketika menejemen diet berhasil dilakukan di rumah belum tentu juga berhasil di luar rumah. Dalam rangka menunjang keberhasilan diet di luar rumah maka diperlukan dukungan dan kerja sama antar beberapa pihak yang terkait dengan anak ketika di luar rumah diantaranya adalah pihak sekolah seperti guru dan teman sekolah, tetangga dan teman bermain di sekitar rumah, serta seluruh keluarga.

Bagian terpenting bagi penderita Diabetes Mellitus adalah pengendalian kadar gula darah. Terapi pada pasien pasien Diabetes Mellitus berhasil salah satunya dapat dilihat dari stabilitas kadar glukosa darah. Oleh karena itu dibutuhkan untuk memahami mengenai hal-hal yang mempengaruhi pengendalian kadar gula darah. Pengendalian kadar gula darah adalah menjaga kadar gula dalam darah berada pada kisaran normal sehingga dapat terhindar dari hiperglikemia atau hipoglikemia (Soegondo, dalam Dewi. 2018).

Kadar glukosa darah yang stabil dipengaruhi oleh beberapa faktor, yairu faktor diet, aktivitas fisik, kepatuhan terapi dan pengetahuan. Peningkatan intake makanan berlemak jenuh serta penurunan makanan berserat dapat mengakibatkan menurunnya kesensitifan insulin dan ketidaknormalan toleransi glukosa. (WHO dalam Dewi. 2018).

Perubahan pola makan secara konsisten harus dilakukan oleh penderita diabetes. Pengaturan makan dapat meningkatkan sensitifitas reseptor insulin sehingga dapat menurunkan kadar glukosa dalam darah (Waspadji dalam Dewi. 2018). Ketidakpatuhan penderita terhadap pengendalian dapat berdampak negative terhadap kesehatannya. Apabila kadar gula 
darah tidak terkontrol maka komplikasi akut seperti hipoglikemi dan ketoasidosis diabetikum dapat terjadi, dan apabila tidak segera ditangani komplikasi tersebut dapat membahayakan bagi individu.

Tema 2 : Mengkomunikasikan Tentang Penyakit Kepada Orang Lain di Luar Rumah (Sekolah/ Teman-Teman, Tetangga)

Ketoasidosis diabetikum (KAD) merupakan salah satu bentuk komplikasi diabetes yang tidak dapat diabaikan, sebagai akibat dari kekurangan insulin akut dalam tubuh dan merupakan penyebab paling banyak dari angka kesakitan dan kematian individu dengan diabetes mellitus tipe 1 (DMT1). Walaupun demikian mayoritas kejadian $\mathrm{KAD}$ dapat dicegah dengan beberapa cara yaitu menejemen terapi insulin yang sesuai serta deteksi dini pada penderita diabetes mellitus yang masih baru.

Pemberian pendidikan kesehatan untuk penderita diabetes mellitus dapat menjadi solusi untuk mencapai tingkat kesehatan yang baik. Pendidikan pasien harus mencakup informasi tentang cara menyesuaikan insulin selama masa sakit dan cara memantau kadar glukosa dan keton, serta informasi tentang pentingnya kepatuhan pengobatan (Dyanne PW. 2013).

Penderita yang telah menyadari akan penyakitnya dibutuhkan untuk melakukan menejemen diri untuk mengontrol kadar glukosa darah secara teratur, melakukan konseling, serta perawatan berkelanjutan (Chafe dkk, 2015). Pemberian pendidikan kesehatan tentang DM tidak hanya dibutuhkan untuk meningkatkan pengetahuan penderita tetapi juga oleh pihak penunjang lain seperti penyedia pelayanan kesehatan, guru serta orang tua selaku keluarga terdekat penderita yang akan berhubungan langsung dengan penderita (Shaltout et al. 2016).

Dukungan keluarga sangat berperan dalam pengelolaan diabetes mellitus. Keluarga mempunyai perspektif yang unik tentang tantangan yang harus dihadapi dalam keseharian dan dukungan untuk meningkatkan menejemen diri penderita. Peran keluarga khususnya orang tua juga termasuk termasuk untuk memberikan informasi kepada pihak sekolah tentang penyakit yang diderita oleh puta putri mereka (Chafe dkk, 2015). Informasi yang diberikan dapat berupa keadaan anak serta menejemen penatalaksanaan misalnya bahwa anak harus membawa obat ke sekolah untuk diinjeksikan sesuai waktu dosis dan waktu yang sudah ditentukan, jenis makanan atau minuman yang boleh atau yang tidak boleh dikonsumsi oleh anak serta aktifitas yang dapat ditoleransi oleh tubuh anak. Kerjasama antara penderita dan keluarga dalam menejemen diabetes mellitus dapat memberikan dampak luar biasa termasuk dalam mencegah terjadinya komplikasi ketoasidosis diabetik.

\section{Tema 3: Melakukan Injeksi Insulin}

Diabetes melitus termasuk golongan penyakit metabolik ditandai dengan peningkatan kadar glukoa darah disebabkan karena kelainan sekresi insulin, kerja insulin, atau kedua-duanya (ADA. 2010). Apabila tidak ditangani dengan baik dapat menyebabkan terjadinya komplikasi yang mengancam kesehatan penderita. Penyakit ini inklusif penyakit kronis yang tidak dapat disembuhkan, tetapi penderita tetap berhak untuk mencapai taraf kesehatan yang maksimal dengan cara mematuhi enam pilar penatalaksanaan diabetes yaitu: terapi insulin, diet, exercise, monitor gula darah, menejemen stres dan pendidikan kesehatan.

Injeksi insulin adalah salah satu kunci keberhasilan pengobatan pada penderita diabetes. Anak dengan DM tipe 1 harus disuntik insulin setiap hari setiap akan makan dan tidur. Proses ini membutuhkan adaptasi yang baik dari penderita sehingga tidak membuat anak menjadi bosan dan tidak mau disuntik lagi. Dalam hal ini dibutuhkan pendekatan interpersonal dari penyedia pelayanan kesehatan pada keluarga. Karena peran orang tua sangat dibutuhkan untuk selalu memberikan motivasi dan pendampingan dalam perawatan anak. Hal tersebut sesuai dengan hasil penelitian yang dilakukan oleh Firdausi dkk (2016) yang menyebutkan bahwa terdapat hubungan anatara dukungan keluarga dengan kepatuhan melakukan latihan fisik dan terapi insulin.

Mempertimbangkan bahwa diabetes melitus tipe 1 ini adalah penyakit kronis yang membutuhkan perawatan berkelanjutan oleh keluarga terdekat, maka orang tua sangat membutuhkan pendidikan kesehatan yang tepat dengan tujuan untuk meningkatkan pemahaman tugas orang tua mengenai permasalahan pada diabetes, pengambilan keputusan yang menunjang perawatan anak yang sakit DM, merawat serta melakukan modifikasi sistem dalam lingkungan keluarga untuk menjamin perawatan maksimal dapat terwujut (Hasbi, 2012).

Hal-hal yang dapat dilakukan orang tua dalam mendukung terapi insulin pada anak berjalan lancar adalah membuat jadwal dan menjelaskan pentingnya injeksi insulin teratur bagi anak, mengajari cara injeksi pada anak, menyiapkan insulin di tempat yang anak ketahui, serta mendampingi anak ketika melakukan suntik insulin. Anak dengan dukungan orang tua yang kuat cenderung lebih patuh terhadap terapi 
pengobatan. Semakin tinggi dukungan orang tua semakin tinggi pula kepatuhan anak.

\section{Tema 4: Pengawasan Diet}

Sebagian besar keluarga penderita diabetes melitus tipe 1 hanya mengetahui bahwa anak tidak boleh mengkonsumsi makanan manis, jumlah makan harus dikurangi dari porsi yang biasanya terutama nasi dan diharapkan untuk banyak makan sayur, namun untuk pengaturan yang lebih detail seperti perhitungan kalori dan takaran pasti yang harus dimakan anak tiap hari setiap jadwal makan partisipan tidak tahu.

Terapi diet adalah salah satu pilar pengendalian diabetes melitus. Petugas kesehatan meletakkan harapan yang besar atas kepatuhan penderita dalam menjalankan diet. Namun demikian bukan hal yang mudah bagi penderita apalagi pada usia anak untuk mengikuti aturan diet DM. Anak usia sekolah yang cenderung mudah suka dengan makanan yang dibeli di sekolah bersama teman-teman dan makanan cepat saji merupakan salah satu penghambat keberhasilan terapi diet ini.

Orang tua khususnya ibu dituntut untuk mampu mengimplementasikan program diet dari dokter untuk anak dengan cara misalnya membuat makanan sehat yang menarik nafsu makan anak sehingga tidak membeli makanan di luar rumah dan minat makan di rumah tinggi karena jenis makanan juga diatur dalam diet DM. Selain itu dapat juga memotivasi anak untuk makan sesuai aturan. Anak dengan banyak motivasi, perhatian dan bantuan dari orang terdekat akan lebih mudah dalam mematuhi program terapi diet (Pratiwi dalam Senuk dkk, 2013).

Selain jenis makanan, jadwal makan juga harus tepat dan teratur. Dukungan keluarga sangat mempengaruhi ketepatan jadwal makan pada anak yang menderita diabetes. Kepatuhan untuk menepati jadwal makan menjadi prioritas utama yang harus dilakukan karena hal ini berkaitan dengan dosis dan waktu untuk melakukan injeksi insulin. Terjadinya komplikasi pada mayoritas penderita diabetes dapat terjadi karena ketidakpatuhan terapi diet. Tingkat kepatuhan penderita pada tatalaksana diet dapat mempengaruhi terhadap terjadinya komplikasi (Mansjoer dkk dalam Risnasari, 2014).

Terdapat beberapa faktor yang mempengaruhi keberhasilan program terapi diantaranya adalah : faktor predisposisi, sosial ekonomi, kepercayaan, pendidikan, dan pengetahuan,sarana kesehatan, serta faktor penguat pendukung seperti perilaku petugas kesehatan dan tokoh agama atau tokoh masyarakat (Notoatmodjo dalam Risnasari, 2014). Kepatuhan diet yang dilakukan dapat berupa tidak melakukan perubahan atas diet yang sudah diatur baik jenis, jumlah maupun jam.

\section{Tema 5: Kunjungan Rutin ke Rumah Sakit}

Hasil penelitian menunjukkan bahwa seluruh partisipan melakukan kunjungan rutin ke rumah sakit apabila insulin akan habis sehingga dibutuhkan untuk mengambil lagi untuk persedian hari-hari berikutnya. Pada kunjungan inilah partisipan dilakukan pemeriksaan glukosa darah dan melakukan konseling hal-hal yang terjadi selama satu bulan sebelumnya.

Kontrol gula darah secara teratur merupakan bagian dari pilar tatalaksana pada diabetes melitus sebagai bentuk evaluasi yang perlu dilakukan secara berkala (Perkeni,2011). Pemeriksaan glukosa darah secara teratur dilakukan sebagai bentuk evaluasi pengobatan yang telah dilakukan, apakah mencapai target atau belum serta bertujuan untuk penyesuaian dosis insulin. Kunjungan ke pelayanan kesehatan secara rutin menunjang terkontrolnya kadar glukosa darah sehingga kejadian komplikasi baik kronis dan akut seperti ketoasidosis diabetik dapat dihambat dan dicegah.

Beberapa faktor yang dapat mempengaruhi kontrol rutin glukosa darah adalah tingkat pendidikan, tingkat pengetahuan, waktu atau jarak tempuh tempat tinggal dengan layanan kesehatan, dukungan tenaga kesehatan serta dukungan keluarga (Albherta dalam Priharianto, 2014). Menemani dan mendampingi anak melakukan kunjungan bulanan ke rumah sakit merupakan bentuk dukungan orang tua pada anak. Selain itu dapat juga menjadi sarana diskusi atau konseling antara orang tua dengan dokter dan petugas kesehatan terkait.

\section{KESIMPULAN DAN SARAN}

\section{Kesimpulan}

Berdasarkan hasil penelitian didapatkan kesimpulan bahwa dukungan keluarga dalam mencegah kejadian KAD pada anak dapat berupa tindakan orang tua membawakan bekal makanan atau minuman ketika anak di luar rumah dan mengkomunikasikan tentang penyakit anak pada pihak terkait di luar rumah (sekolah, teman dan tetangga).

\section{Saran}

Pentingnya peran orang tua terhadap keberhasilan terapi diabetes melitus tipe 1 dan dalam pencegahan terjadinya komplikasi ketoasidosis diabetik, menuntut kemampuan lebihpada orang tua untuk mengetahui dan memahami dengan baik tentang menejemen 
diabetes serta kemampuan untuk mengimplemetasikan pemahamannya.

Orang tua harus lebih siap dengan segala kemungkinan terjadinya komplikasi akut KAD, seperti deteksi dini dan tersedianya emergency callnumber terdekat dalam rangka penanganan awal serangan.

Berkurangnya kunjungan di emergency

\section{REFERENSI}

Chafe, R., Albrechtsons, D., Hagerty, D., Newhook, L.A. (2015). Reducing episodes of diabetic ketoacidosis within a youth population: a focus group study with patients and families. BMC. BMC Res Notes. DOI 10.1186/s13104-0151358-7

Dewi, Erika U. (2018). Gambaran faktor-faktor yang mempengaruhi terkendalinya Kadar gula darah pada pasien diabetes mellitus Di puskesmas pakis surabaya. Ejournal. Stikeswillianbooth. Vol. 4, no. 2

Dyanne, P.W. (2013). Diabetic Ketoacidosis: Evaluation and Treatment. American Family Physician. Vol. 87 Issue 5, p337-346. 10p. 2 Charts.

Hasbi, M (2012). Analisa Faktor Yang Berhubungan Dengan Kepatuhan Penderita Diabetes Melitus dalam Melakukan Olahraga di Wilayah Kerja Puskesma Praya Lombok Tengah, Tesis, Depok: Universitas Indonesia Fakultas Ilmu Keperawatan UI.

Perkeni. (2011). Konsensus Pengelolaan dan Pencegahan Diabetes Melitus Tipe 2 di Indonesia. Jakarta: PB. PERKENI

Priharianto, Anan., Maliya, Arina., Rosyid, F.N. (2014). Hubungan Antara Dukungan Keluarga Dengan Keteraturan Kontrol Kadar Gula Darah Pada Penderita Diabetes Melitus Di Wilayah Puskesmas Bendosari Sukoharjo. Skripsi. Universitas Muhammadiyah Surakarta. department dan rumah sakit untuk kasus KAD dapat memberikan dampak yang sangat besar terhadap kesehatan masyarakat. Maka peran aktif petugas kesehatan dalam memberikan informasi atau update pengetahuan orang tua dalam perawatan anak sangat diperlukan, sehingga kejadian ketoasidosis diabetik dapat dicegah.

Risnasari, Norma. (2014). Hubungan Tingkat Kepatuhan Diet Pasien Diabetes Mellitus Dengan Munculnya Komplikasi Di Puskesmas Pesantren kota Kediri. Jurnal Universitas Nusantara PGRI Kediri. Jurnal Nomor 25 Volume 01

Senuk, A., Supit, W., Onibala, F. (2013). Hubungan Pengetahuan dan Dukungan Keluarga Dengan Kepatuhan Menjalani Diet Diabetes Melitus. Ejournalkeperawatan (e-Kp) Volume 1 Nomor 1

Shaltout, Azza A., Channanath, AM., Thanaraj, TA., Omar, D., Abdulrasoul, M., Zanaty, N., Almahdi, M., Alkandarr, H., AlAbdulrazzaq, D., D’mello, L., Mandani, F., Alanezi, A, Albasiry, E., Alkhawarr, M. (2016). Ketoacidosis at First Presentation Of Type One Diabetes Mellitus Among Children: A Study From Kuwait. Scientific Reports. DOI 10.1038/srep27519

Susanti, M.L dan Sulistyarini, T. (2013). Family Support Increasing The Diet Compliance Diabetes Mellitus Patients In Inpatient Ward Of Kediri Baptist. Jurnal STIKES Volume 6. No. 1

Usher-Smith, J.A., Thompson, M.J; Sharp, S.J., Walter, F.M. (2011). Factors associated with the presence of diabetic ketoacidosis at diagnosis of diabetes in children and young adults: a systematic review. BMJ. doi: 10.1136/ bmj. d4092 